\title{
FINANCIAL INTERMEDIATION AND ENTREPRENEURIAL ACTIVITY
}

\section{Radim Boháček}
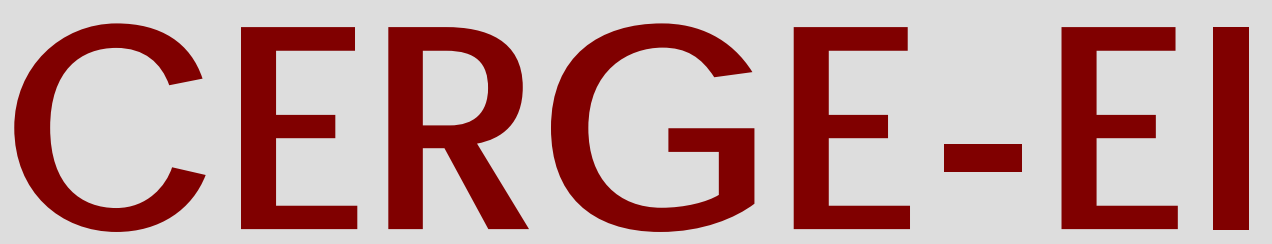

Charles University Centerfor Economic Research and Graduate Education Academy of Sciences of the Czech Republic Ec onomic s Institute 
Working Paper Series

198

(ISSN 1211-3298)

\title{
Financial Intermediation and Entrepreneurial Activity
}

Radim Boháček

\author{
CERGE-EI
}

Prague, April 2002 
ISBN 80-86286-79-7 (Univerzita Karlova v Praze, CERGE)

ISBN 80-86288-73-0 (Národohospodářský ústav AV ČR, Praha) 


\title{
Financial Intermediation and Entrepreneurial Activity
}

\author{
Radim Boháček* \\ CERGE-EI, Prague, Czech Republic
}

July 3,2002

$\therefore$

$\because \quad$ Abstract

This paper studies the effects of financial intermediation on aggregate levels and the distribution of resources in an economy with wealthconstrained heterogeneous agents and occupational choice. Whether an agent becomes an entrepreneur depends on a realized entrepreneurial ability and accumulated assets needed to finance a business project with uncertain returns. I compare a steady state of an economy with financial intermediation to an economy in which entrepreneurs must funance their projects only from their savings. The simulated benchmark economy matches well the U.S. data on the distribution of occupations and resources. The efficiency and welfare losses in the economy without financial intermediation are large and since the workers bear most of the adverse effects, the economy is also more unequal. Finally, a transition from the steady state of the economy without financial intermediation simulates the process of financial development: both measures of inequality decline monotonically during the transition.

JEL Classification: E44, G20, J24, 016

Keywords: Financial intermediation, occupational choice, general equilibrium, economic development

"I am very grateful to Galyna Vereshchagina for her excellent research assistance and the seminar participants at CERGE-EI, University of Cyprus, and University of Stockholm for helpful comments and suggestions. All errors are mine. Address: CERGE-EI, Politickych veznu 7, 111 21 Prague 1, Czech Republic. Email: radim.bohacek@cergè-ei.cz 


\begin{abstract}
Abstrakt
Tato práce studuje efekty finančnich thỉ na agregátni veličiny a rozložení zdrojů v ekonomii s heterogennimi agenty s omezeným majetkem a volbou povolání. Zda agent bude zaměstnavatelem závisí na realizované podnikatelské schopnosti a naakumulovaném majetku, jehož je potřeba $k$ financování podnikatelského projektu s nejistým ziskem. Srovnávám ustálený stav ekonomie s finančním trhem $\mathrm{s}$ druhou ekonomií, kde agenti musí financovat své projekty pouze ze svého mäjetku. Simulovaná první ekonomie odpovídá statistickým údajủm v USA, včetně rozložení povolání a zdrojů. Ztráty efektivity a welfare v ekonomii bez finančních trhů jsou velké. Vzhledem $\mathrm{k}$ tomu, že většina záporných efektů dopadá na dělníky, nerovnost v ekonomii roste. Závěrem analyzuji proces přechođu z ustáleného stavu ekonomie bez finančniho trhu, který Tento proces simuluje prüběh rozvoje finančních trhů. Obě měřtka nerovnosti klesají během celého transitiviniho procesu.
\end{abstract}




\section{Introduction}

We have entirely lost the idea thai any undertaking likely to pay, and seen to be likely, can perish for want of money; yet no idea was more familiar to our ancestors, or is more common in most countries. A citizen of Long in Queen Elizabeth's time ... would have thought that it was no use investing railways (if he could have understood what a railway meant), for you would have not been able to collect the capital with which to make them. At this moment, in colonies and all rude countries, there is no large sum of transferable money; there is not fund from which you can borrow, and out of which you can make immense works.

Walter Bagehot. Lombard Street (1873, pp. 3-4)

One of the important differences between individual countries is the development of financial markets. In developed countries, and not in the underdeveloped ones, there typically exist a highly organized and broad system of financial intermediation designed to facilitate the flow of loanable funds between savers and entrepreneurs. The efficiency and sophistication of an economy's financial market is considered as one of the most important determinants of general economic activity and growth (see Levine (1997) for a survey of the literature). Access to and the cost of financial intermediation influence the entrepreneurial choices of asset-constrained agents and determine whether good business ideas become implemented in practice. This paper studies the effects of existence of financial intermediation on aggregate levels and the distribution of resources in an economy with wealth-constrained heterogeneous agents and occupational choice.

Economic literature provides two main theories that link financial markets to economic activity and growth. The first one argues that the economic activity itself creates a demand for financial services. The second one sees financial services as a prerequisite for economic activity and development. In this paper, I build a model around the second hypothesis. I analyze and numerically simulate a dynamic, general equilibrium model with heterogeneous agents in which each agent faces the following option: to work as a worker or to become an entrepreneur. A worker receives a wage while an entrepreneur establishes a firm with capital 
investment, employs other agents as workers, and realizes profit from a decreasing returns to scale production technology. Each agent compares the value he or she would obtain from employment to the expected net value of the profits accruing from running a firm. However, entrepreneurship is not only a profitable but also a riskier occupation. Entrepreneurs in the model invest into one irreversible project with uncertain returns. In fact, if a risk-averse entrepreneur must invest disproportionately in the illiquid project, he may forgo the plan and work for a wage.

The availability and cost of borrowed funds needed for entrepreneurial projects constitute different opportunities and prospects for wealth-constrained agents. I compare the steady states of two economies that differ only in the existence of financial intermediation. The benchmark economy calibrated to the U.S. data is characterized by a financial intermediation system in which competitive banks offer one-period capital loans at a market clearing interest rate and workers are hired at an equilibrium wage. The other economy has only a labor market where workers sell their labor to entrepreneurs who finance their projects out of their own savings. Each economy exhibits a different stationary equilibrium with a fraction of the agents being entrepreneurs and the remaining fraction workers, as well as different levels of aggregate allocations, productivity, welfare, and an endogenous distribution of wealth and income.

The existence of financial intermediation, a level of accumulated individual wealth and an idiosyncratic entrepreneurial ability are the decisive forces behind each agent's ability to finance and undertake an entrepreneurial project. Bank loans allow agents with high entrepreneurial skills to start a new business even if they could not finance the project from their own savings. On the other hand, the absence of financial intermediation precludes agents with low savings from becoming entrepreneurs even if they have very good skills. Thus there are two main incentives for the agents to accumulate more wealth that cannot be addressed in a model with a representative agent: first is the incentive to save in order to accumulate assets needed for undertaking an entrepreneurial project in the presence of wealth constraints. The second incentive is the precautionary savings against unin- 
surable idiosyncratic risk: agents that become entrepreneurs face higher expected income but also a much higher income uncertainty than workers.

The simulated benchmark economy matches very well the U.S. data on distribution of occupation and resources. In particular, its steady state replicates the Gini coefficients of inequality for wealth and income, the distribution of assets and income in the top percentiles, and the different shares of wealth and income of each occupation. The importance of financial intermediation for the U.S. economy is documented by its dramatically different steady state allocations and distribution of resources. The otherwise same economy without financial intermediation is about $22 \%$ less efficient and the average agent's welfare loss equals $25.6 \%$. Perhaps surprisingly, workers suffer the most as the general equilibrium halves their wages. As a consequence, the Gini coefficients of wealth and income inequality increase. In the equilibrium without inancial intermediation, entrepreneurs are more constrained, and their projects are of lower quality. I find that the dominant factor behind the high levels of savings of business families is the incentive to accumulate assets in order to overcome the wealth constraint in financing the entrepreneurial projects.

Finally, I simulate the process of financial development by a transition to the steady-state of the benchmark economy by introducing banks into the steady state of the economy without financial intermediation. In the transition, the average worker and the average agent are better off (in terms of the present discounted value by $68 \%$ and $37 \%$, respectively), while the average entrepreneur suffers a welfare loss of $8.5 \%$. Both Gini indexes of wealth and income inequality monotonically decline during the whole transition process. Compared to other papers (Greenwood and Jovanovic (1990), among others) financial development in this model makes the society less unequal with no evidence of the inverted-U shaped Kuznets curve. The subsequent sections analyze the results of the numerical simulation in great detail.

The modelling strategy departs from the neoclassical theory of investment with a representative agent: where, according to the Modigliani-Miller theorem, the firm's choice of the optimal capital stock could be solved without reference to financial factors. Instead, it follows the Lucas (1978) study of business firms' 
size and the Lucas (1990) and Fuerst (1992) models of loanable funds. Compared to more recent models of occupational choice (Quadrini (1999a), De Nardi and Cagetti (2001), Erosa (2001), Jeong and Townsend (2001), or Gomes, Greenwood, and Rebelo (2001)) this model preserves the simplicity of the general equilibrium neoclassical models with added ex ante uncertainty related to returns on entrepreneurial projects. Its purpose is to isolate the effects of financial intermediation without complicating the analysis with overlapping generations, default, exogenous fixed and entry costs, or exogenously specified sectors of production.

There is a large literature on the importance of funcial markets for general economic activity and economic growth, for example. Gertler (1988), Bencivenga and Smith (1991), and Greenwood and Jovanovic (1990). Levine (1997), King and Levine (1993a) and King and Levine (1993b) find that depth and liquidity of financial rnarkets are statistically significant for real per capita GDP growth, the average rate of growth in the capital stock per capita, and total productivity growth. As far as the causality is concerned, King and Levine (1993a) suggest that the initial level of financial development is a good predictor of subsequent rates of economic growth, physical capital accumulation, and economic efficiency over the next 30 years even after controlling for income, education, political stability, and government policies.

Of the usual functions of financial system surveyed in the above literature, I linit my attention to financial intermediation by a competitive banking sector. I do not model any market frictions (information or transaction costs) or monitoring managers and corporate control (see Stiglitz (1992) for a survey). In order to meaningfully compare the two economies, I focus on their steady state levels. For these reasons I abstract from modelling growth, institutional development, human capital and technological innovation, population growth and other phenomena that are very important for studying financial markets in developing countries.

The next Section surveys the empirical evidence on entrepreneurial choice and distribution of resources in the U.S. economy. Section 3 develops the main model and defines stationary recursive equilibrium. Characterization of occupational decisions are described in. Section 4. Parameters and numerical simulations are 
presented in Section 5. Section 6 contains the results of numerical simulations. Section 7 concludes.

\section{Data on Entrepreneurial Activity in the United States}

This Section presents a brief description of the data on entrepreneurial activity in the United States. In the following Sections I will calibrate the benchmark economy with financial intermediation to replicate these data.

In the 1994 Panel Study of Income Dynamics (PSID), 10.4\% of families own a business or have a financial interest in some business enterprise. Hereafter, I use this definition of entrepreneurship. ${ }^{1}$ The average number of entrepreneurs in PSID between 1970 and 1992 was $12 \%$.

Wealth is much more concentrated than income. The Gini coefficient for family wealth is between 0.78 and 0.84 , depending on the year and survey (PSID and the Survey of Consumer Finances (SCF), respectively). The Gini coefficient for family income is 0.45 in the PSID and declines to 0.34-0.36 after government transfers (Mitchell (1991)). In the PSID, the top 1 percent of families owns around $29 \%$ of the total household wealth and around $8 \%$ of the total income. The top 5 percent owns already $50 \%$ of the wealth and receives $20 \%$ of the income. Finally, the top docile owns around $60 \%$ of the wealth and receives $31.5 \%$ of the income. These numbers are usually higher by 10 percent in the SCF surveys.

The percentage of business families increase in higher wealth classes: Quadrini (1999a) documents that about half of the families in the top $5 \%$ are business families. However, the concentration of wealth among business families is not purely explained by the concentration of income. Entrepreneurs, being such a small fraction of the population, receive $22 \%$ of the total income and own $40 \%$

\footnotetext{
${ }^{1}$ Among entrepreneurs, more than $75 \%$ own only one business. An alternative definition of entrepreneurship considers families in which the head of the household is self-employed in his or her main job ( $9.9 \%$ of the population). I will use the terms business owner and entrepreneur interchangeably.
} 
of the total wealth. In other words, entrepreneurial families own higher levels of wealth relative to their income than worker families: the ratio of wealth to income is about twice as large for business families. Quadrini (1999b) and Gentry and Hubbard (1999) find that entrepreneurs are wealthy because they not only earm more income but also save relatively more than workers.

The undertaking of entrepreneurial activity is an important way for households to switch to higher classes of wealth. Quadrini (1999a) uses the PSID data to observe that while worker families tend to stay in or move to lower positions of wealth, business households tend to stay in or move to higher positions. Also, he finds that the longer the business life, the higher the wealth accumulated by business families. According to data collected by the Bureau of the Census in the Characteristics of Business Owners and Employees (CBO 1992), 73\% of the owners of businesses with fewer than 500 employees were original founders, $11 \%$ received the firm as a transfer (gift), another $11 \%$ purchased the firm, $3 \%$ inherited the firm, and the remaining $2 \%$ acquired the firm in other ways. Original founders are less prevalent in larger firms.

Entrepreneurial income is more volatile than the labor income of workers.' Heaton and Lucas (2000) found that the median standard deviation of the growtil rate of nonfarm proprietary income is $64 \%$ annually, and the median standard deviation of the growth rate of real wage income is only $35 \%$ annually. According to the CBO 1992, around $35 \%$ of business owners received more than three-quarters of their total income from their business. Proportionately more entrepreneurs who run small firms receive all income from their firm's profit.

Are entrepreneurs constrained by their wealth? Evans and Leighton (1989) in their"study of entrepreneurship based on the National Longitudinal Survey find that then with greater assets are more likely to become self-employed all else being equal. Holtz-Eakin, Joulfaian, and Rosen (1994) document in their inheritance study that liquidity constraints exert a noticeable influence on the viability of entrepreneurial enterprises. The CBO 1992 shows that three-quarters of small firms use credit, almost $60 \%$ use traditional as well as non-traditional sources. For both sources the usage of credit grows with firm size. In terms of the aggregate value of 
small firm debt, almost $90 \%$ of credit comes from traditional sources, mostly from lines of credit and loans: Commercial banks are the traditional financing source most often used by $37 \%$ of small firms, contributing to $54 \%$, or $\$ 361$ billion, of finañcès. Firms with assets of less than $\$ 250$ million get most of their debt finance from banks while firms: with assets of more than $\$ 1$ billion finance more than $85 \%$ of their new debt through nonbank sources.

Finally, the Federal Reserve Survey of Terms of Business Lending reveals that small loans are more often secured by collateral. In 2000 , for example, of all commercial and industrial loans made by all commercial banks in the United States, $83 \%$ required collateral for loans smaller than $\$ 99,000,74 \%$ for loans smaller than $\$ 1$ million, $46.9 \%$ for loans smaller than $\$ 10$ million, and only $31.7 \%$ for loans greater than $\$ 10$ million. Evans and Jovanovic (1989) estimate in their model that entrepreneurs can borrow up to $50 \%$ of their assets.

As far as the sources of non-borrowed capital are concerned, almost half of the entrepreneurs use their own or family's savings and smaller entrepreneurs also use physical assets. Fazzari, Hubbard, and Petersen (1988) report that internal finance in the form of retained earnings generates the majority of net funds for firms of all size categories. The average retention ratio is largest for small firms $(80 \%)$ and lowest for the largest firms (50\%). Eisner (1978) finds that the timing of investment in small frms is more sensitive to profits than it is in large firms.

A firm's employment size affects the firm's dynamics. Davis, Haltiwanger, and Schuh (1996) show that the rates of job creation and job destruction in U.S. manufacturing firms decrease in firm size and that, conditional on the initial size, small firms grow faster than large firms. Evans (1987) shows that the growth rate of manufacturing firms and the volatility of growth is negatively correlated with firm size and age. Cooley and Quadrini (2001) label these refutations of the Gibrat's Law - that firm size and growth are independent -as "size dependence" and "age dependence", respectively. Quadrini (1999a) shows that the entrance rate for business owners averages $3.7 \%$; the entrance rate for business owners with previous experience is $23 \%$, and without $2.6 \%$. Notably, $64 \%$ of owners have previous work experience in a managerial capacity and $34 \%$ as the owner 
of another business. The exit rate is highest for the new entrants: while the average exit rate is $24 \%$, entrepreneurs with only one year of experience the exit rate is $45 \%$, with two years $31 \%$, and with three years and more $13 \%$. On the other hand, using the CBO data, the average business termination rate is almost constant around $14 \%$ between 1990 and 1997. The combination of low exit rates and high entrance rates of experienced business families implies their low turnover rate and high entrepreneurial persistence. This persistence allows business families to accumulate higher levels of wealth relative to workers.

The above data indicate that entrepreneurial activity is a very important feature of the U.S. economy. Accumulated experience and wealth, together with access to financial services, seem to be the main determinants of entrepreneurial activity. Especially small firms play an important role in innovation, technological change and productivity growth. In the 1990s, small businesses employed more than half of the workforce and created three-fourths of the new jobs. At the same time, the owners of small firms seem to be the most constrained by their wealth.

In the next Section, I will model the business experience as a persistent Markov process of entrepreneurial ability. Finally, as the entrepreneurs most often rely on commercial banks as their main source of borrowing, I will define financial intermediation as a competitive banking sector offering one period capital loans. In the United States, domestic credit provided by the banking sector is $164 \%$ of GDP, which is around five times more than in poor countries according to the surveys by the World Bank.

\section{The Model}

In this Section I develop a model of the benchmark economy with functioning capital and labor markets and defne a stationary recursive equilibrium'. Later, the benchmark economy is modified to an economy without financial intermediation.

The economy is populated by a continuum of infinitely lived agents on a unit 
interval. Each agent has preferences over consumption given by a utility function

$$
E\left[\sum_{t=0}^{\infty} \beta^{t} u\left(c_{t}\right)\right]
$$

where $\beta \in(0,1)$ and $u: \mathbb{R}_{+} \rightarrow \mathbb{R}$ is bounded, strictly increasing, strictly concave, and a twice differentiable continuous function that satisfies the Inada conditions.

In the beginning of a period each agent is identified by a level of accumulated assets $a \in A=[0, \infty]$ and by an ability shock $z \in Z=[\underline{z}, \bar{z}]$. The ability shock is carried from the previous period and is interpreted as a signal for an effective ability shock $z^{\prime} \in Z$ that is realized later in the current period.

Production of the consumption good occurs in a large number of firms. Each firm is owned and managed by one entrepreneur who rents capital $k$ and hires workers $n$ in competitive factor markets. An entrepreneur with effective ability $z^{\prime}$ produces output $y=z^{\prime} f(k, n)=z^{i}\left(k^{\alpha} n^{1-\alpha}\right)^{\theta}$, where $\alpha \in(0,1)$ and $\theta<1$. The production function exhibits decreasing return to managerial control as in Lucas (1978). These assumptions preclude pyramidal managerial structure and ensure that even the best managers run projects of a finite size. Capital used in production depreciates at a rate $\delta \in(0,1)$.

In the economy with financial intermediation there is a competitive banking sector with which agents deposit their accumulated assets. As there is no cost of intermediation, the banks pay the same equilibrium interest rate on deposits, $r$, as they receive for one period capital loans lent to the firms. There is a competitive labor market where firms hire workers at an equilibrium wage $w$.

Given the individual state $(a, z)$ at the beginning of the period, each agent decides whether to work as a worker or whether to become an entrepreneur. If the agent becomes a worker, he or she draws the effective ability shock $z^{\prime}$, from a fixed distribution $\psi$ and receives labor income $z^{\prime} w l$ where $l=1$ is the normalized working time.

If the agent becomes an entrepreneur, he or she cannot work for a wage but must decide how much capital; $k$, to borrow from a competitive banking sector and how much effective labor supply, $n$, to contract before the effective ability 
shock $z^{\prime}$ is drawn. Given the decreasing returns to scale technology, the realized profit share is $1-\theta$. Of course, if the ability shock turns out to be very low, the entrepreneur's profit is negative since he or she must repay the loan, $(r+\delta) k$, and the contracted workers, $w n$.

The forgone'wage serves as an endogenous entry cost for entrepreneurs. Therefore, it will not be optimal to establish a firm of a very small size with expected profits much lower than the expected wage which could be earned by joining the labor force. Entrepreneurial risk is another cost of establishing a business. Each entrepreneur faces a positive probability of realizing a very low effective ability shock and having a negative profit he or she must expense from the accumulated assets. With the entrepreneurial project committed before the effective ability shock is realized, agents with a low level of assets will not take any or at, least large entrepreneurial projects because they would not be able to cover the potential loss in the case of failure. In the whole paper I assume full information and no possibility of default. I also assume that a project's failure does not lead to a full depreciation of the capital used in production, or in other words; that the capital is not project-specific.

Note that if the agents could choose their occupation after they observe the effective ability shock, all agents with high shocks would become entrepreneurs and employ the profit-maximizing inputs regardless of their wealth. Since the purpose of this study is occupational choice for agents constrained by their wealth, I model the entrepreneurial decision as an ex ante commitment of resources with uncertain return. The labor contracts are also made before the effective ability shock is realized so that unsuccessful entrepreneurs cannot work for a wage later on. This setup can be interpreted as if the loan and workers are paid before the sale revenues (or demand shocks) are realized. Finally, I assume that there are no markets in which the agents can insure against these idiosyncratic shocks.

Shocks for the entrepreneurs follow a first-order Markov process with a transition function $Q\left(z, z^{\prime}\right)$. The Markov structure of shocks to entrepreneurial ability reflects the learning aspect of entrepreneurial success as documented in Quadrini (1999a). I assume that $Q$ is monotone and satisfies the Feller property. Because of 
the i.i.d. structure of workers' ability shocks, I assume that each firm hires workers of the same average effective ability $\int z^{\prime} \psi\left(d z^{\prime}\right)$.

I abstract from a fixed cost associated with operating a business modelled in Hopenhayn and Rogerson (1993), among others. Instead, I follow Veracierto (2001) in specifying the set of entrepreneurial ability shocks $Z=\{\underline{z}\} \cup[1, \bar{z}]$. To ensure that not all agents become entrepreneurs, I assume that $\underline{z}$ is such a low entrepreneurial skill with $Q(\{\underline{z}\},\{\underline{z}\})=1$ that agents with this signal always prefer to become workers. Second, to guarantee the exit of entrepreneurs, I assume that $Q(z,\{\underline{z}\})>0$ for all $z \in Z$. The values of the shocks and the structure of the transition matrix will be specified in detail in the following Sections. ${ }^{2}$

After the labor income or profits are realized, both, workers and entrepreneurs decide on how much to consume and on the amount of assets. invested to the next period. Each agent carries his or her effective ability shock $z^{\prime}$ drawn after the occupational choice as the next period signal for future effective ability shocks.

The decision of an agent identified by the asset level and ability signal, $(a, z)$, can be formalized by the following recursive optimization problem

$$
v(a, z)=\max \left\{\int v^{W}\left(a, z^{\prime}\right) \psi\left(d z^{\prime}\right), \max _{k, n} \int v^{E}\left(a, z^{\prime}\right) Q\left(z, d z^{\prime}\right)\right\}
$$

where the choice of being a worker has a value

$$
v^{W}\left(a, z^{\prime}\right)=\max _{c, a^{\prime}}\left\{u(c)+\beta v\left(a^{\prime}, z^{\prime}\right)\right\}
$$

subject to a budget constraint

$$
c+a^{\prime} \leq(1+r) a+z^{\prime} w l
$$

Becoming an entrepreneur has a value, given the choice of capital investment, $k$, and hired labor; $n$,

$$
v^{E}\left(a, z^{\prime}\right)=\max _{c, a^{\prime}}\left\{u(c)+\beta v\left(a^{\prime}, z^{\prime}\right)\right\}
$$

\footnotetext{
${ }^{2}$ Observe that if workers did not draw their idiosyncratic ability shocks, over time all agents would be of the same occupation and the equilibrium would not exist.
} 
subject to a budget constraint

$$
c+a^{\prime} \leq(1+r) a+\pi\left(k, n, z^{\prime}\right)
$$

where $\pi\left(k, n, z^{\prime}\right)$ is the entrepreneur's profit;

$$
\pi\left(k, n, z^{\prime}\right)=z^{\prime} f(k, n)-(r+\delta) k-w n \text {. }
$$

Finally,

$$
a \in A \text { with } \underline{a}=0, \text { and } k, n \geq 0, l=1 .
$$

Note that it is optimal for an agent who decides to be a worker not to take any loan. Vice versa, an entrepreneur always takes a positive loan. The production technology implies that all entrepreneurs operate with the same capital-labor ratio. The next Section will analyze the occupational choice and entrepreneurial decisions in detail.

The specification of the utility function together with the uncertainty in entrepreneurial profits imply that agents with a low level of accumulated assets can be constrained with respect to the size of the entrepreneurial project. In particular, the maximal loan payment and wages for contracted workers must guarantee a nonnegative consumption for all possible realizations of total entrepreneurial income,

$$
(r+\delta) k+w n \leq(1+r) a+z^{\prime} f(k, n) \text { for all } z^{\prime} \in Z
$$

Since in each period $Q(z,\{\underline{z}\})>0$ for all $z \in Z$, this financing constraint must hold for the lowest effective ability shock:

$$
(r+\delta) k+w n \leq(1+r) a+\underline{z} f(k, n) .
$$

As the financing constraint depends only on the asset level and not on the signal of the effective entrepreneurial ability $z$, poor agents with good entrepreneurial ideas will not be able to establish a firm or the firm size will be smaller than it would have been without the financing constraint. Numerical simulations will show that the financing constraint has substantial effects on occupational choice, allocations as well as distribution of resources in the economy. ${ }^{3}$

\footnotetext{
${ }^{3} I$ set $Q(z,\{\underline{z}\})>0$ for all $z \in Z$ in each period only for the sake of the financing con-
} 


\subsection{Stationary recursive equilibrium}

The concept of stationary recursive equilibrium requires that assets supplied by all agents equal the amount of capital demanded by the entrepreneurs, that labor supply by workers equals the labor hired by entrepreneurs, and that all allocations be feasible for a time invariant distribution of agents over their types.

The policy function for the next-period assets $a^{\prime}(a, z)$ and the laws of motion for the ability shock process generate a law of motion for the distribution of agents over their individual states,

$$
\lambda^{\prime}\left(A^{\prime}, Z^{\prime}\right)=\int_{\left\{\left(a, z^{\prime}\right): a^{\prime}\left(a, z^{\prime}\right) \in A^{\prime}\right\}} \Delta\left(z, d z^{\prime}\right) \lambda(d a \times d z)
$$

for all $A^{\prime}$ and $Z^{\prime}$, where $\Delta\left(z, d z^{\prime}\right) \equiv Q\left(z, d z^{\prime}\right)_{\mid E}+\psi\left(d z^{\prime}\right)_{j W}$ selects the law of motion for entrepreneurs' and workers' ability shocks. The probability measure $\lambda$ describes the fractions of agents with the same individual state. According to this law of motion; the fraction of agents that will begin next period with assets in the set $A^{\prime}$ and a signal of ability in the set $Z^{\prime}$ is given by all those agents that transit from their current shock $z$ to a shock in $Z^{\prime}$ and whose optimal decision for assets accumulation belongs to $A^{\prime}$. Compared to many models in the literature on financial intermediation and occupational choice, the distribution of agents is endogenous.

It is now possible to state the definition of a stationary recursive equilibrium.

Definition 1 A stationary recursive competitive equilibrium is constant factor prices $(r, w)$, value functions $v(a, z), v^{E}(a, z), v^{W}(a, z)$, policy functions $k(a, z), n(a, z), c\left(a, z^{\prime}\right), a^{\prime}\left(a, z^{\prime}\right)$, a probability measure $\lambda$, transition selector $\triangle\left(z, d z^{\prime}\right)$, and aggregate levels $(A, K, L, N)$, such that

1. at prices $(r, w)$, the policy functions solve the optimization problem of each agent $(a, z)$,

2. the probability measure $\lambda$ is time invariant,

straint. Stationary equilibrium with an endogenous distribution of agents would also exist for $Q^{N}(z,\{\underline{z}\})>0$ for all $z \in Z$ in a finite number of periods $N>0$. 
3. the capital and labor markets clear,

$$
\begin{gathered}
A=\int a \lambda(d a \times d z)=\int k(a, z) \lambda(d a \times d z)=K, \\
L=\int z^{\prime} \Delta\left(z ; d z^{\prime}\right) \lambda(d a \times d z)=\int n(a, z) \lambda(d a \times d z)=N,
\end{gathered}
$$

4. and the aggregate feasibility constraint holds at equality

$$
\begin{aligned}
\int\left\{c\left(a, z^{\prime}\right)\right. & +\delta k(a, z)\} \Delta\left(z, d z^{\prime}\right) \lambda(d a \times d z)= \\
& =\int z^{\prime} f(k(a, z), n(a, z)) Q\left(z, d z^{\prime}\right) \lambda(d a \times d z) .
\end{aligned}
$$

The aggregate feasibility constraint is implied from the other market clearing conditions by the Walras' law and that the fraction of entrepreneurs is equal to $1-L$.

\subsection{An Economy without Financial Intermediation}

An economy without financial intermediation differs from the benchmark economy only in the absence of the banking sector. All agents have access to storage technology that does not bring any return. Thus all entrepreneurs must finance projects from their accumulated assets. There still exists a labor market where workers can be hired at an equilibrium wage $w$. Otherwise, the structure of the two economies is identical and I continue to assume that assets used in production depreciate at a rate $\delta \in(0,1)$.

The problem of an agent $(a, z)$ becomes

$$
v(a, z)=\max \left\{\int v^{W}\left(a, z^{\prime}\right) \psi\left(d z^{\prime}\right), \max _{k, n} \int v^{E}\left(a, z^{\prime}\right) Q\left(z, d z^{\prime}\right)\right\}
$$

where the choice of being a worker has a value

$$
v^{W}\left(a, z^{\prime}\right)=\max _{c, a^{\prime}}\left\{u(c)+\beta v\left(a^{\prime}, z^{\prime}\right)\right\}
$$

subject to a budget constraint

$$
c+a^{\prime} \leq a+z^{\prime} w l
$$


Becoming an entrepreneur has a value, given $(k, n)$,

$$
v^{E}\left(a, z^{\prime}\right)=\max _{c, a^{\prime}}\left\{u(c)+\beta v\left(a^{\prime}, z^{\prime}\right)\right\}
$$

subject to a budget constraint

$$
c+a^{\prime} \leq a+\pi\left(k, n, z^{\prime}\right)
$$

where $\pi\left(k, n, z^{\prime}\right)$ is the entrepreneur's profit (or loss)

$$
\pi\left(k, n, z^{\prime}\right)=z^{\prime} f(k, n)-\delta k-w n
$$

and the no-borrowing constraint

$$
k \leq a
$$

Finally, an entrepreneur with no access to financial intermediation faces a modified financing constraint,

$$
\delta k+w n \leq a+\underline{z} f(k, n) .
$$

Note that an entrepreneur does not have to use all assets in production. The definition of the stationary recursive equilibrium is similar to that of the benchmark economy except for the market clearing condition in the asset market. If the equilibrium exists, i.e., if there is a positive fraction of workers (entrepreneurs), the total amount of capital used in production is strictly smaller than the total amount of assets in the economy, $K<A$.

\section{Characterization of Entrepreneurial Decisions}

This Section partially characterizes occupational choices and entrepreneurial decisions. The occupational choice of each agent is based on the comparison of the expected present discounted value of each occupation. The existence of a stationary recursive equilibrium requires that there be a positive fraction of the population in each occupation. The following assumptions guarantee, first, that there exists a shock sufficiently high that some agents become entrepreneurs, and second, that for a shock sufficiently low each agent prefers to be a worker. 
Assumption 1 The signal ability shock $\bar{z}$ is such that there exists an asset level $a^{s}$ for which $\int v^{W}\left(a, z^{\prime}\right) \psi\left(d z^{\prime}\right) \leq \int v^{E}\left(a, z^{\prime}\right) Q\left(\bar{z}, d z^{\prime}\right)$ for all $a \geq a^{s}$.

Assumption 2 The signal ability shock $\underline{z}$ is such that $\int v^{W}\left(a, z^{\prime}\right) \psi\left(d z^{\prime}\right) \geq$ $\int v^{E}\left(a, z^{\prime}\right) Q\left(\underline{z}, d z^{\prime}\right)$ for all $a \in A$.

Note that both assumptions are related to the opportunity cost of forgone wages. The first assumption guarantees the entrepreneurs above the switching level of assets that in expectation the value of their occupation choice is greater than the value of choosing to work for wage, and vice versa for the second assumption.

The properties of value functions for each occupation follow the analysis in Stokey, Lucas, and Prescott (1989). The value function of workers $v^{W}\left(a, z^{\prime}\right)$ is strictly increasing in each argument since the utility function is strictly increasing and strictly concave and a worker's constraint set is strictly increasing in assets and the effective ability shock. The same properties apply to the value function of entrepreneurs for all $\left(a, z^{\prime}\right)$.

The expected value function of workers is independent of $z$ and an increasing and continuous function of $a$. Due to the monotonicity of the transition matrix $Q$, the expected value function of entrepreneurs is an increasing and continuous function of both $a$ and $z$. Finally, the value function $v(a, z)$ is non-decreasing in $z$ and strictly increasing in $a .^{4}$

Figure 1 displays values related to the occupational decision of agents with three levels of signal: low, $z_{L}$, medium, $z_{M}$, and high, $z_{H}$. As the value function of: entrepreneurs is increasing in and that of workers independent of the signal ability shock, it can be easily shown that for each $z$ there is either none or at most one switching level of assets $a^{s}(z)$ and that $a^{s}(z)$ decreases in $z$. All of the above properties hold in all numerical simulations of the model.

\footnotetext{
${ }^{4}$ The value function $v(a, z)$-the outer envelope for the value functions at each shock levelmay not be a concave function even if the value functions of workers and entrepreneurs are. Gomes, Greenwood, and Rebelo (2001) analyze a model of unemployment with a similar property. The operator on the value function satisfies the Blackwell's sufficient conditions for a contraction mapping.
} 
In Figure 1 for given prices, all agents below $a^{s}\left(z_{H}\right)$ are workers. Agents with the high signal ability shock switch to entrepreneurship at $a^{s}\left(z_{H}\right)$, agents with the medium signal shock at $a^{s}\left(z_{M}\right)$, while agents with $z_{L}$ never become entrepreneurs (there is no switching level of assets for this signal ability shock). Thus signals $z_{H}$ and $z_{M}$ satisfy assumption 1 and the signal $z_{L}$ satisfies assumption 2 . At asset level $a_{1}$ only agents with $z_{H}$ are entrepreneurs while at asset level $a_{2}$ agents with both $z_{H}$ and $z_{M}$ are entrepreneurs.

At a given level of signail ability shock $z \in Z$, agents identified by the state $\left(a^{s}(z), z\right)$ are indifferent between working and undertaking an entrepreneurial project. Therefore, it must be the case that

$$
\int v^{W}\left(a^{s}(z), z^{\prime}\right) \psi\left(d z^{\prime}\right)=\int v^{E}\left(a^{s}(z), z^{\prime}\right) Q\left(z, d z^{\prime}\right)
$$

The first order intertemporal condition for an agent with accumulated assets $a$ and a realized effective ability shock $z^{\prime}$ is just $u_{c}\left(c\left(a, z^{\prime}\right)\right)=\ddot{\beta} v_{a}\left(a^{\prime}\left(a, z^{\prime}\right), z^{\prime}\right)$ as there is no uncertainty about the agent's next period state. Using the usual envelope conditions and assuming interior solutions, the condition (17) can be rewritten, dropping the term $(1+r) \beta$ on both sides, as

$$
\int v_{a}\left(a^{\prime}\left(a^{s}(z), z^{\prime}\right), z^{\prime}\right) \psi\left(d z^{\prime}\right)=\int v_{a}\left(a^{\prime}\left(a^{s}(z), z^{\prime}\right), z^{\prime}\right) Q\left(z, d z^{\prime}\right)
$$

Note that the left-hand side is independent of $z$ while the right-hand side is increasing in $z$ due to the properties of $Q$. The different sources of income and the separate laws of motion of ability shocks imply that the policy finctions $a^{\prime}\left(a^{s}(z), z^{\prime}\right)$ are different for each occupation at the same effective ability shock $z^{\prime}$.

$\because$ If for some $z \in Z$

$$
\int z^{\prime} \psi\left(d z^{\prime}\right)<\int z^{\prime} Q\left(z, d z^{\prime}\right)
$$

becoming an entrepreneur has a future value. In other words, marginal entrepreneurs are willing to sacrifice current consumption for having the opportunity to begin their business career. ${ }^{5}$ Therefore, for such agents the expected current

\footnotetext{
${ }^{5}$ This result also holds for some non-marginal entrepreneurs: due to the continuity of the value function for each occupation, entrepreneurs with assets $\left[a^{g}(z), a^{s}(z)+\epsilon\right)$, where $\epsilon>0$, also also willing to sacrifice current consumption for the future flow of profits.
} 
income from business is lower than the expected wage,

$$
\int z^{\prime} w \psi\left(d z^{\prime}\right)>\int z^{\prime} f(k, n) Q\left(z, d z^{\prime}\right)-w n-(r+\delta) k .
$$

It is the dynamic and learning aspect of entrepreneurship contained in the Markov process (the future value increases in its-monotonicity) that precludes writing the within period break-even condition at equality as in Lucas (1978). This result corresponds to the empirical finding that especially the entrants to entrepreneurial occupation have a lower income than if they continued to be workers (see Hamilton (2000)). In the search model with occupational choice by Gomes, Greenwood, and Rebelo (2001), consumption of searchers similarly decreases compared to workers who keep their jobs.

Whether entrepreneurs are financially constrained depends on their asset position, ability and the optimal size of the project. If they are unconstrained, the first order conditions with respect to committed capital and labor inputs are,

$$
. \int u_{c}\left(c\left(a, z^{\prime}\right)\right)\left[z^{\prime} f_{k}(k(a, z), n(a, z))-(r+\delta)\right] Q\left(z, d z^{\prime}\right)=0
$$

and

$$
\int u_{c}\left(c\left(a, z^{\prime}\right)\right)\left[z^{\prime} f_{n}(k(a, z), n(a, z))-w\right] Q\left(z, d z^{\prime}\right)=0
$$

respectively. Thus all entrepreneurs use the same optimal capital-labor ratio,

$$
x \equiv \frac{k(a, z)}{n(a, z)}=\frac{\alpha}{1-\alpha} \frac{w}{r+\delta}
$$

I now turn to the analysis of the optimal size of the entrepreneurial project measured in terms of employment level (similar results apply to the optimal levels of capital input). When the financing constraint is not binding at the optimal level of inputs, i.e., if

$$
((r+\delta) x+w) n(a, z)<(1+r) a+\underline{z} f(n(a, z) x)
$$

the hiring policy is independent of the entrepreneur's wealth and depends only on the signal ability $z$. Denote such unconstrained employment levels as $n^{u}(z)$. When the financing constraint (22) binds, entrepreneurs are not able to run a 
project at the optimal size and their hiring decisions depend on their wealth. A binding financing constraint (22) can be solved for a level of $n^{b}(a)$ independent of the signal ability shock. ${ }^{6}$

In general, an optimal hiring policy must satisfy

$$
n(a, z) \leq \min \left\{n^{u}(z), n^{b}(a)\right\}
$$

The actual employment size is a function of the expected marginal utilities and productivity for all levels of the effective ability shocks. Figure 2 shows the hiring constraints for the three shock levels used in Figure 1. The unconstrained policies are horizontal lines $n^{u}(z)$, while the asset-constrained biring policy lies on the increasing concave function $n^{b}(a)$. The employment levels of entrepreneurs with the high ability signal must lie below the thick line $n\left(a, z_{H}\right)$. Entrepreneurs with the medium signal shock are unconstrained. It is apparent that wealthy agents are more likely to be:unconstrained than poorer agents.

When entrepreneurial decisions are not constrained by wealth, the size of business projects is optimal and the allocations efficient. This applies to entrepreneurs with asset level $a_{2}$ and high and medium signal shocks. At $a_{1}$ agents with a medium signal shock choose to be workers. Finally, agents with a low signal shock are always workers with $n\left(a, z_{L}\right)=0$.

Agents with accumulated assets $a_{1}$ and the high signal shock cannot hire the optimal employment level $n^{\nu}\left(z_{H}\right)$ but must use at most a lower, inefficient level $n^{b}(a)$. If they received a bequest or inherited additional assets, their project would increase to its optimal size (see the evidence in Holtz-Eakin, Joulfaian, and Rosen (1994)). Agents with a high signal shock but very low assets $a<a^{s}\left(z_{H}\right)$ must choose to be workers. ${ }^{7}$

Similar results apply to the economy without financial intermediation where the agents no longer receive a return on their assets. For $k \leq a$, all entrepreneurs

\footnotetext{
${ }^{6} \mathrm{As}$ the financing constraint affects both inputs symetrically, the capital-labor ratio continues to hold at the same level.

${ }^{7} \mathrm{~A}$ binding financing constraint adds the Lagrange multiplier associated with the financing constraint, multiplied by $(I+r)$, also to the right-hand side of (18). Thus the future value of a constrdined entrepreneurship is lower.
} 
now face the cost of the capital project $\delta k$ instead of receiving the non-negative income $(r+\delta)(a-k)$. As all projects with $k>a$ are not possible, the occupational choice of agents with good entrepreneurial ideas but low assets is now restricted.

\section{Numerical Simulation}

The complex general equilibrium effects, especially the nontrivial role of the interest rate in entrepreneurial decisions, requires a numerical simulation. In this Section I specify the parameters for the benchmark economy and outline the computational algorithm. All parameters, chosen to match the United States data, are shown in Table 1.

The main features of the U.S. data reviewed in Section 2 are reflected in the specification of the shock structure. Entrepreneurs and workers must share the beginning of the period shock, i.e., the signal for the effective ability shock that will be realized after they choose their occupation. However, as the workers' shocks are iid, it is possible to set the values of effective ability shocks different for each occupation. In other words, the signal ability shock $z$ plays a role only as a position of the current state in the Markov transition matrix $Q$ for the occupational decision.

Another reason for splitting the effective ability shocks for the occupations is the problem of providing a positive income to workers with no assets and at the same time setting the effective ability shock $\underline{z}$ low enough to satisfy the assumption 2. With $\underline{z}=0$ for entrepreneurs, I choose the workers' lowest effective ability shock to equal one half with a probability of $\psi(\underline{z})=0.05$. It is as if the workers become unemployed with a very low probability and receive unemployment benefits equal to one half of the equilibrium wage. This shock structure does not effect the hiring decision of entrepreneurs (the average productivity can always be normalized to one) and simplifies the model with no need to deal explicitly with a subsidy to agents with no income via taxation.

As in Veracierto (2001) the effective ability shocks for the entrepreneurs $Z^{E}=\{0\} \cup[1, \bar{z}]$ with $Q(\{0\},\{0\})=1$ so that an entrepreneur who fails with 
the lowest effective ability shock will prefer to be a worker in the following period. Also, $Q([1, \bar{z}],\{0\})>0$ implies that all entrepreneurs terminate their businesses in finite time. This specification of shocks and their laws of motion imposes the financing constraint in each period and satisfies the assumptions on the existence of a stationary equilibrium. Setting the lowest effective ability $\underline{z}=0$ simplifies the constrained hiring rule to a linear function of the asset level, share of labor in the production function, and equilibrium prices, $n^{b}(a)=(1-\alpha)(1+r) a / w$.

The technology specification is standard for the U. S. economy as in Cooley (1995). The utility has the logarithmic form and the span of managerial control $\theta$ is set at a level which leaves the appropriate share of national income going to owners of the enterprises as in the United States data.

The algorithm for finding the steady state of each regime is relatively simple. To solve for the occupational decision, expected values of both options are computed first. For a given interest rate, I iterate on the wage until the labor market is cleared with the optimal policies and the stationary distribution obtained for these prices. If the market for capital is cleared too, the steady state has been found. Otherwise, I increase the interest rate if there was an excess demand in the capital market and vice versa for an excess supply. For the economy without financial intermediation the interest rate is fixed at zero. Finally, I set the maximal level of assets high enough so that the upper bound of the stationary distribution of resources is endogenous.

\section{Results}

In this Section I present the results of numerical simulations of the stationary equilibria for the benchmark economy and the economy without financial intermediation. Finally, I simulate a transition between these two steady states to illustrate the process of financial development. 


\subsection{The Benchmark Economy}

Steady state allocations of the benchmark regime are shown in the first column of Table 2. The proportion of entrepreneurs is 9.1\%, matching the data for the U.S. economy. Importantly, this model with entrepreneurs can replicate the different Gini coefficients for wealth, 0.82 , and income, 0.33 , inequality. ${ }^{8}$ The top percent of the agents own $29.7 \%$ of the total wealth and receive $11.6 \%$ of the total income. The top $5 \%$ own more than half of the total wealth and receive one quarter of the total income.

Table 3 shows average levels and shares for each occupation. While the wealth/income ratios of entrepreneurs and workers match the data exactly (twice as high as for entrepreneurs than for workers), the workers' shares of wealth and income are a little bit low. This is because the entrepreneurs receive all the profits. If workers could hold shares of the firms, this statistics would improve. Thus in this model the entrepreneurs hold ten times more assets, receive four times more income, and consume more than two times more than the workers. The entrepreneurs are the investors in the economy. Their total investment is $49 \%$ of the total assets and the average entrepreneur invests almost $9 \%$ of the assets he owns. On the other hand, the workers invest very little. These results confirm the finding in Quadrini (1999a) that it is the entrepreneurial persistence that leads to the high concentration of wealth and especially to the very high concentration of wealth by business families.

The average entrepreneurial return on projects is $6.77 \%$ (see Table 4). Also, $89 \%$ of entrepreneurs are net borrowers, using on average 2.03 times mare capital than they hold assets. As in Huggett (1997), borrowing constraints in a model with heterogeneous agents leads to over savings in the sense that the equilibrium interest rate lies below the rate of time preference. The total credit in the economy (i.e, the total assets provided by the workers) is $168 \%$ of the output, matching very well

\footnotetext{
${ }^{8}$ Wealth is measured simply as the level of assets accumulated by each agent. The latter coefficient is smaller than the pre-transfer U.S. measure. As the model contains a transfer system for agents with no assets and the lowest productivity shock, the fit to the post-transfer income inequality is good.
} 
the same statistics for the U.S. economy. Note that small entrepreneurs borrow from the banks more frequently than large entrepreneurs, which is also consistent with the data. The share of small firms (under 10 employees) is $71 \%$.

Figure 3 displays several features of the occupational decision making process in the benchmark economy. The top-left panel shows expected profits for all levels of signalled entrepreneurial ability. Agents with a high shock expect very large profits. The decreasing returns to scale technology makes the profits flat when the size of the project reaches its optimum for unconstrained agents with high levels of accumulated assets. The top-right panel shows profit levels for all possible realizations of the effective ability shock, given the optimal input choices associated with the high signal ability shock. The loss for the largest failed project is huge, amounting to one quarter of accumulated assets of those entrepreneurs who are able to undertake them.

The bottom-left panel shows the occupational choice for the poorest agents (working for wage is labelled as zero, entrepreneurship as one). Agents with the high signal shock switch first, while the agents with the fifth highest shock switch to entrepreneurship at much higher asset levels. Finally, the bottom-right panel shows that especially the least wealthy entrepreneurs derive most of their income from business. Only the most wealthy agents who are net lenders obtain most of their total income from the interest income on their deposits.

Figure 4 displays a short occupational history of an agent who in the first ten periods worked as a worker. In period 11 he received a very good signal ability shock and switched to entrepreneurship, taking a capital loan (solid line in the left panel). Note that because the signal ability shock was known already before the end of period 10, the agent lowered his consumption (solid line in the right panel) and saved more (dashed line) in order to arrive at the next period with an asset level that would minimize the financial constraint and allowed a more optimal investment decision. In other words, he behaved according to the theory in the previous Section. ${ }^{9}$

\footnotetext{
${ }^{9}$ The future value of entrepreneurship is so high that in some cases an agent runs a business project in spite of expecting a five times lower business income than he would receive as a worker.
} 
The project was successful for ten periods and good profits led to a fast accumulation of assets. The entrepreneur became less constrained and borrowed more to run his business at a more optimal size. After three periods, his consumption rose above the level he had as a worker. Entrepreneurial career reached its peak in period 20. The next period the project failed when the entrepreneur drew the lowest ability shock. Working for a wage became a more valuable choice than entrepreneurship. Finally, note the consumption smoothing and fall in the asset level in the remaining periods.

\subsection{The Economy Without Financial Intermediation}

The average :per-capitallevels for the economy without financial intermediation are shownilinfable 2 , second column. The third column calculates the change with respect to the benchmark economy. Without financial intermediation, output declines" by $22.5 \%$ and the agents suffer a welfare loss equal to $25: 6 \%$. Efficiency, measured as output per effective labor, falls by $21.8 \%$. As there is no borrowing and lending, only $68 \%$ of the assets are used in production, which is about $11 \%$ less than the benchmark economy's steady state capital stock.

Compared to the benchmark economy, agents accumulate much more assets they need for financing the entrepreneurial projects from their own savings (the investment-output ratio is 0.21 compared to 0.18 in the benchmark economy). Thus the wealth of business families is even higher because they increase their savings to overcome the now more binding wealth constraint they face in undertaking entrepreneurial projects. This coincides with the conclusion of Holtz-Eakin, Rosen, and Willen (2001) who found that the willingness to accept risk is not a dominant factor in the decision to become self-employed.

While the fraction of agents in each occupation is very similar, the Gini coefficients of inequality are much worse: 0.93 for wealth and 0.44 for income. The inequality rises also within each occupation: for example, in the benchmark economy, the Gini coefficient of wealth inequality is 0.60 for entrepreneurs and 0.81 for workers (these numbers roughly correspond to U.S. data). These measures now 
increase to 0.73 and 0.94 , respectively. Accordingly, agents in the top percentiles own much more wealth and receive more income than in the benchmark economy (note the huge increases for the top percentiles!).

The main reason for the widening inequality is the deteriorated situation of workers. General equilibrium effects turn to be the crucial force: equilibrium wage in the modified economy must decrease by more than $40 \%$ for the labor market to clear. At higher wages the entrepreneurs would not be willing to hire workers and undertake their business projects. Higher returns to entrepreneurship relative to working for a wage increased the ranks of entrepreneurs by one tenth.

Lower labor income worsens the position of workers relative to entrepreneurs and to the benchmark economy, as shown in Table 3. Despite constituting $90 \%$ of the population, the workers' share of wealth declines to one third, income to $51 \%$, and consumption to $63 \%$. Because of the lower wage and no return on assets, the average income decreases for both occupations.

Workers' average welfare loss is a staggering $39.6 \%$ of their average consumption in the benchmark economy. On the other hand, the entrepreneurs' welfare increases by $10.1 \%$. This is due to the higher level of accumulated assets and the fact they demand almost tree times the return on their projects they had in the economy with functioning financial intermediation. Again, the high return is an equilibrium incentive for the agents to accumulate assets needed to finance the business projects.

From Table 4 one can read that the projects are smaller: on average, the employment level decreases by almost twenty percent. Entrepreneurs now use on average $94 \%$ of their own assets. The quality of entrepreneurial projects, measured by the average entrepreneurial effective ability, decreases by more than 8 percent. This is due to the more binding financial constraints when agents with good skills but limited assets do not become entrepreneurs (the share of small firms grows to $81 \%$ ).

Some of the two economies' allocations are compared in Figure 5. Note that ernployment policies in the benchmark economy (top-left panel) are much less constrained than in the economy without financial intermediation (top-right panel). 
For example, entrepreneurs in the benchmark economy with 1,000 units of accumulated assets and high shock hire one third more workers despite the higher wages they must pay. How much constrained they are can be read from the bottom panels: agents in the benchmark economy with low assets borrow more than four times their savings. Entrepreneurs with the high signal shock are net borrowers up to very high asset levels in order to operate at the optimal project size. In the economy without financial intermediation the capital-asset ratio is bounded by one; it is less than one for agents whose capital inputs are optimally smaller than their savings:

\subsection{The Process of Financial Development}

The transition process from the steady state of the economy without financial intermediation to the benchmark steady state is shown in Figures 6 and 7. The transition allocations are based on the optimal behavior of agents after the introduction of financial intermediation into the original steady state. The economy converges from the inherited state of the economy without financial intermediation, namely its distribution of assets, to the steady state of the benchmark economy. The markets clear in each period and the evolution of the distribution is based on the optimal investment decisions of all agents. Each agent solves the transition path backwards from the steady state of the benchmark economy, having rational expectations about the evolution of prices in all transition periods. In equilibrium, these expectations of all agents are correct. Computationally, I fix the number of transition periods, $T$, and guess the evolution of the distribution and prices, $\left\{\lambda_{t}, r_{t}, w_{t}\right\}_{t=0}^{T}$, where $\left(\lambda_{0}, r_{0}, w_{0}\right)$ and $\left(\lambda_{T}, r_{T}, w_{T}\right)$ are known from the two steady states. I iterate on the guess and a sufficient length of the transition until convergence. Standard proofs in Stokey, Lucas, and Prescott (1989) can be used to prove its existence.

In Figure 6, the time paths of the market clearing prices are shown in the right panels, the levels of aggregate capital (now equal to the aggregate assets) and labor are in the left panels. The interest raterises monotonically, assuring 
that in each period of the transition the capital stock demanded by entrepreneurs equals the stock of assets in the banks. Wage jumps.immediately to a level even higher than that in the benchmark economy's steady state. Note that at a higher level of labor income many more agents prefer to be workers. Entrepreneurs are now less constrained, poor entrepreneurs with good skills can run their projects (the average entrepreneurial skill increases). The inefficiently high stock of assets declines smoothly to the new equilibrium level, together with the capital/labor ratio.

In its top panels, Figure 7 shows the evolution of output as well as of consumption and income for both occupations (relative to the original steady state levels). With the appearance of the banking sector, output per capita increases immediately. by $30 \%$ and income of workers more than doubles. In terms of expected discounted present value derived from consumption, the introduction of banks makes the workers better off by $68.4 \%$ and the average agent by $37 \%$. Entrepreneurs is the only group of agents that is worse worse off: their average welfare decreases by $8.5 \%$ (observe the decline in their average consumption in the top-left panel).

The bottom panels show the evolution of the Gini coefficients of inequality for wealth and income. Both inequality indexes decline monotonically during the whole transition. All agents now receive a return $\left(r_{t}+\delta\right)$ on their deposits and have more incentives to save (especially the workers with now higher incomes). On the other hand, the income of entrepreneurs is lower due to the lower return to entrepreneurship. The transition experiment with the introduction of financial intermediation makes the society less unequal with no evidence of the inverted-U shaped Kuznets curve.

\section{Conclusions}

This paper evaluated the effect of financial intermediation on economic activity and distribution of resources in a calibrated U.S. economy. By construction, removing financial intermediation represents a limit on all agents' allocations and 
must be inefficient: : Numerical simulations showed that the efficiency and welfare losses exceed $20 \%$; magnitudes not usually found in other models studying; for example, inefficienciès in governinent policies. These results confirm the importance of financial intermediation for efficient allocation of resources and the empirical findings of Levine (1997), King and Levine (1993a) and King and Levine (1993b).

This model shows that modelling the occupational decisions of heterogenous agents is important for matching the U.S. distributional data. In particular, entrepreneurial choice and profit are able to generate a very unequal distribution of wealth. For agents differentiated by their wealth, the access to and the cost of borrowed funds determine their occupational choice, the size of their entrepreneurial projects and savings decisions.: The main factor behind the high levels of savings of business families is the incentive to accumulate assets in order to overcome the wealth constraint in financing the entrepreneurial projects.

What is important with respect to economic development, financial intermediation improves not only the aggregate levels of output or welfare but also alleviates inequality, both of wealth and income. Perhaps surprisingly, the general equilibrium effect associated with the process of financial intermediation significantly improves the wellbeing of workers and of poor agents in relative as well as in absolute terms.

The assumptions in this paper are very few and the model displays simplicity of the basic neoclassical macroeconomic models. The effects of other:important features of financial intermediation--asymmetric information, possibility of default, collateral requirements or property rights-on the allocation and distribution of resources are left for future research. 


\section{References}

Bencivenga, V. R. and B. Smith (1991). Financial intermediation and endogenous growth. Review of Economic Studies (58), 195-209.

Cooley, T. F. (Ed.) (1995). Frontiers in The Business Cycle Research (1 ed.). Princeton, New Jersey: Princeton University Press.

Cooley, T. F. and V. Quadrini (2001). Financial markets and firm dynamics. New York University Working Paper.

Davis, S., J. Haltiwanger, and S. Schuh (1996). Job Creation and Desctruction. Cambridge, MA: MTT Press.

De Nardi, M. and M. Cagetti (2001). Entrepreneurship, default risk, bequests and wealth inequality. Working Paper.

Eisner, R. (1978). Factors in business investment. Cambridge: Ballinger Press.

Erosa, A. (2001). Financial intermediation and occupational choice in development. Review of Economic Dynamics 4, 303-334.

Evans, D. S. (1987). Tests of alternative theories of firm growth. Journal of Political Economy 95(4), 657-674.

Evans, D. S. and B. Jovanovic (1989). An estimated model of entrepreneurial choice under liquidity constraints. Journal of Political Economy $97(4), 808-$ 827.

Evans, D. S. and L. S. Leighton (1989). Some empirical aspects of entrepreneurship. American Economic Review 79(3), 519-535.

Fazzari, S. M., G. R. Hubbard, and B. C. Petersen (1988). Financing constraint and corporate investment. Brookings Papers on Economic Activity (1), 141195.

Fuerst, T. S. (1992). Liquidity, loanable funds, and real activity. Journal of Monetary Economics 29, 3-24.

Gentry, W. and G. Hubbard. (1999). Entrepreneurship and household savings. Working paper.

Gertler, M. (1988). Financial structure and aggregate economic activity: An overview. Joumal of Money, Credit and Banking 20(3), 559-589.

Gomes, J., J. Greenwood, and S. Rebelo (2001). Equilibrium unemployment. Journal-of Monetary Economics (48), 109-152.

Greenwood, J. and B. Jovanovic (1990). Financial development, growth and the distribution of income. Journal of Political Economy (98), 1076-1107. 
Hamilton, B. H. (2000). Does entrepreneurship pay? an empirical analysis of the returns to self-employment. Journal of Political Economy 108(3), 604-631.

Heaton, J. and D. Lucas (2000). Portfolio choice and asset prices: The importance of entrepreneurial risk. Journal of Finance 55(3), 1163-1198.

Holtz-Eakin, D., D. Joulfaian, and H. S. Rosen (1994). Sticking it out: Entrepreneurial survival and liquidity constraint. Journal of Political Economy 102(1), 53-75.

Holtz-Eakin, D., H. Rosen, and P. Willen (2001). Self-employment and risk. Working Paper.

Hopenhayn, H. A. and R. Rogerson (1993). Job turnover and policy èvaluation: A general equilibrium analysis. Journal of Political Economy 101:(5), 915938.

Huggett, M. (1997). The one-sector growth model with idiosyncratic shocks: Steady states and dynamics. Journal of Monetary Economics 39, 385-403.

Jeong, H. and R. M. Townsend (2001). Models of growth and inequality: An evaluation. Working Paper (1).

King, R. G. and R. Levine (1993a). Finance and growth: Schumpeter might be right. Quarterly Journal of Economics, 717-737.

King, R. G. and R. Levine (1993b). Finance, entrepreneurship, and growth: Theory and evidence. Journal of Monetary Economics 32(3), 513-542.

Levine, R. (1997). Financial development and economic growth: Views and agenda. Journal of Economic Literature 35(2), 688-726.

iLucas, Jr., R. E. (1978). On the size distribution of business firms. Bell. Journal " of Economics 9, 508-523.

Lucas, Jr., R. E. (1990). Liquidity and interest rate. Joumal of Economic Theory $50,237-264$.

Mitchell, D. (1991). Income Transfers in Teñ Welfärè States (1 ed.). Brookfield, USA: Avebury.

Quadrini, V. (1999a). Entrepreneurship, saving and sociall inobility. Duke University and CEPR working paper.

Quadrini, V. (1999b). The importance of entrepreneurship for wealth concentration and mobility. Review of Income and Wealth .45(1), 1-19.

Stiglitz, J. E. (1992). Asymmetric information in icredit markets and its implications for macroeconomics. Oxford Economic Papers 44 (4), 694-724.

Stokey, N. L., R. E. Lucas, Jr., and E. C. Prescott (1989). Recursive Methods in Economic Dynamics. Cambridge: Harvard University Press. 
Veracierto, M. (2001). Employment flows, capital mobility, and policy analysis. International Economic Review 42(3), 571-595. 


\begin{tabular}{|c|c|c|c|c|c|c|c|c|c|}
\hline \multicolumn{10}{|c|}{ Parameters of the Model } \\
\hline \multicolumn{10}{|c|}{ Technology and Preferences } \\
\hline & & & $\alpha$ & $\theta$ & $\delta$ & $\beta$ & & & \\
\hline & & & 0.34 & 0.90 & 0.07 & 0.95 & & & \\
\hline \multicolumn{10}{|c|}{ Workers' Effective Ability Shocks $Z^{W}$} \\
\hline 0.5 & 1 & 1.5 & 2 & 2.5 & 3 & 4 & - & - & - \\
\hline \multicolumn{10}{|c|}{ Entrepreneurs' Effective Ability Shocks $Z^{E}$} \\
\hline 0 & 0 & 1 & 1.25 & 1.5 & 1.75 & 2 & 2.25 & 2.5 & 2.75 \\
\hline \multicolumn{10}{|c|}{ Distribution $\psi$ of Workers' Ability Shocks } \\
\hline 0.05 & 0.75 & 0.09 & 0.05 & 0.03 & 0.02 & 0.01 & 0 & 0 & 0 \\
\hline \multicolumn{10}{|c|}{ Transition Matrix $Q$ for Entrepreneurs' Ability Shocks } \\
\hline 1 & 0 & 0 & 0 & 0 & 0 & 0 & 0 & 0 & 0 \\
\hline 0 & 1 & 0 & 0 & 0 & 0 & 0 & 0 & 0 & 0 \\
\hline 0.2250 & 0 & 0.7500 & 0.0250 & 0 & 0 & 0 & 0 & 0 & 0 \\
\hline 0.1000 & 0 & 0.0750 & 0.8000 & 0.0250 & 0 & 0 & 0 & 0 & 0 \\
\hline 0.0500 & 0 & 0 & 0.0875 & 0.8500 & 0.0125 & 0 & 0 & 0 & 0 \\
\hline 0.0250 & 0 & 0 & 0 & 0.1125 & 0.8500 & 0.0125 & 0 & 0 & 0 \\
\hline 0.0125 & 0 & 0 & 0 & 0 & 0.1250 & 0.8500 & 0.0125 & 0 & 0 \\
\hline 0.0125 & 0 & 0 & 0 & 0 & 0 & 0.1250 & 0.8500 & 0.0125 & 0 \\
\hline 0.0125 & 0 & 0 & 0 & 0 & 0 & 0 & 0.1250 & 0.8500 & 0.0125 \\
\hline 0.0125 & 0 & 0 & 0 & 0 & 0 & 0 & 0 & 0.1375 & 0.8500 \\
\hline
\end{tabular}

Table 1: Parameters of the Benchmark Model 


\begin{tabular}{|c|c|c|c|}
\hline \multicolumn{4}{|c|}{$\begin{array}{l}\text { Results of Numerical Simulation } \\
\text { Steady State Aggregate Levels and Distribution }\end{array}$} \\
\hline $\begin{array}{l}\text { Per-Capita } \\
\text { Levels }\end{array}$ & $\begin{array}{l}\text { Benchmark } \\
\text { Model }\end{array}$ & $\begin{array}{l}\text { No Financial } \\
\text { Intermediation }\end{array}$ & $\begin{array}{l}\text { Change } \\
(\%)\end{array}$ \\
\hline Output & 3.16 & 2.45 & -22.5 \\
\hline Consumption & 2.54 & 1.89 & -25.6 \\
\hline Assets & 9.67 & 12.63 & 30.6 \\
\hline Capital in Production ${ }^{a}$ & 9.67 & 8.59 & $-11.2(68.1)$ \\
\hline Efficiency ${ }^{b}$ & 2.93 & 2.29 & -21.8 \\
\hline Credit/GDP & 1.68 & 一 & - \\
\hline Interest rate & 0.032 & 一 & $:-$ \\
\hline Wage $\because .$. & 1.61 & 0.94 & -41.6 \\
\hline Workers (\%). & 90.9 & 90.0 & -1.0 \\
\hline Entrepreneurs (\%) & 9.1 & 10.0 & 9.9 \\
\hline \multicolumn{4}{|l|}{ Gini Index } \\
\hline Wealth & 0.82 & 0.93 & 13.4 \\
\hline Income & 0.33 & 0.44 & 33.3 \\
\hline \multicolumn{4}{|l|}{ Top Percentiles (\%) } \\
\hline \multicolumn{4}{|l|}{ Wealth. } \\
\hline $1 \%$ & 29.7 & 43.5 & 46.5 \\
\hline $5 \%$ & 59.7 & 80.2 & 34.3 \\
\hline $10 \%$ & 74.1 & 93.1 & 25.6 \\
\hline \multicolumn{4}{|l|}{ Income } \\
\hline $1 \%$ & 11.6 & 19.5 & 68.1 \\
\hline $5 \%$ & 26.4 & 38.3 & 45.1 \\
\hline $10 \%$ & 36.1 & 47.1 & 30.5 \\
\hline
\end{tabular}

Notes: ${ }^{a}$ The first number in the last column represents the change in capital level used in production in the economy without financial intermediation with respect to the capital in the benchmark economy. The number in parenthesis is the percentage of total assets used in production in the economy without financial intermediation. ${ }^{b} \mathrm{Efficiency}$ measured as output per effective labor.

Table 2: Steady State Aggregate Levels and Distribution 


\begin{tabular}{|c|c|c|c|c|c|c|}
\hline \multicolumn{7}{|c|}{$\begin{array}{l}\text { Results of Numerical Simulation } \\
\text { Entrepreneurs and Workers }\end{array}$} \\
\hline & \multicolumn{3}{|c|}{ Average Levels } & \multicolumn{3}{|c|}{ Shares (\%) } \\
\hline.$\vdots \because$ & $\begin{array}{l}\text { Bench. } \\
\text { Model }\end{array}$ & $\begin{array}{l}\text { No Fin. } \\
\text { Interm. }\end{array}$ & $\begin{array}{c}\text { Change } \\
(\%)\end{array}$ & $\begin{array}{l}\text { Bench. } \\
\text { Model }\end{array}$ & $\begin{array}{l}\text { No Fin. } \\
\text { Interm. }\end{array}$ & $\begin{array}{c}\text { Change } \\
(\%)\end{array}$ \\
\hline \multicolumn{7}{|l|}{ Wealth } \\
\hline Entrepreneurs & 53.05 & 79.10 & 49.0 & 49.7 & 68.7 & 38.2 \\
\hline Workers & 5.33 & 4.43 & -16.9 & 50.3 & 31.3 & -37.8 \\
\hline \multicolumn{7}{|l|}{ Income } \\
\hline Entrepreneurs & 10.65 & 8.55 & $=19.7$ & 30.6 & 48.6 & 58.8 \\
\hline Workers & 2.39 & 1.11 & -53.6 & 69.4 & 51.4 & -25.9 \\
\hline \multicolumn{7}{|l|}{ Consumption } \\
\hline Entrepreneurs & 5.70 & 6.32 & 10.1 & 20.3 & 36.7 & 80.8 \\
\hline Workers & 2.22 & 1.34 & -39.6 & 79.7 & 63.3 & -20.6 \\
\hline
\end{tabular}

Table 3: Entrepreneurs and Workers 


\begin{tabular}{|c|c|c|c|}
\hline \multicolumn{4}{|c|}{$\begin{array}{l}\text { Results of Numerical Simulation } \\
\text { Firms Statistics }\end{array}$} \\
\hline Average & $\begin{array}{c}\text { Benchmark } \\
\text { Model }\end{array}$ & $\begin{array}{c}\text { No Financial } \\
\text { Intermediation }\end{array}$ & $\begin{array}{c}\text { Change } \\
(\%)\end{array}$ \\
\hline Output & 34.93 & 22.39 & -35.9 \\
\hline Capital & 107.79 & 78.47 & -27.2 \\
\hline Employment & 10.07 & 8.22 & -18.4 \\
\hline Profit & 5.80 & 8.55 & 47.4 \\
\hline Return (\%) & 6.77 & 19.6 & 189.5 \\
\hline Capital/Assets & 2.03 & 0.94 & -53.7 \\
\hline Capital/Eff. Labor & 9.03 & 8.05 & -10.8 \\
\hline Capital/Output & 3.08 & 3.50 & 13.6 \\
\hline Output/Eff. Labor & 2.93 & 2.29 & -21.8 \\
\hline Quality & 1.98 & 1.81 & -8.6 \\
\hline Small Firms ${ }^{b}(\%)$ & 71.0 & 81.0 & 14.1 \\
\hline \multicolumn{4}{|l|}{ Borrowing (\%) } \\
\hline All Firms & 88.8 & - & - \\
\hline Small Firms & 96.2 & - & 二 \\
\hline
\end{tabular}

Notes: ${ }^{a}$ Quality measured as entrepreneurial effective ability per firm. ${ }^{b}$ Small firms defined by employment lower than 10 units of effective labor.

Table 4: Firms Statistics 


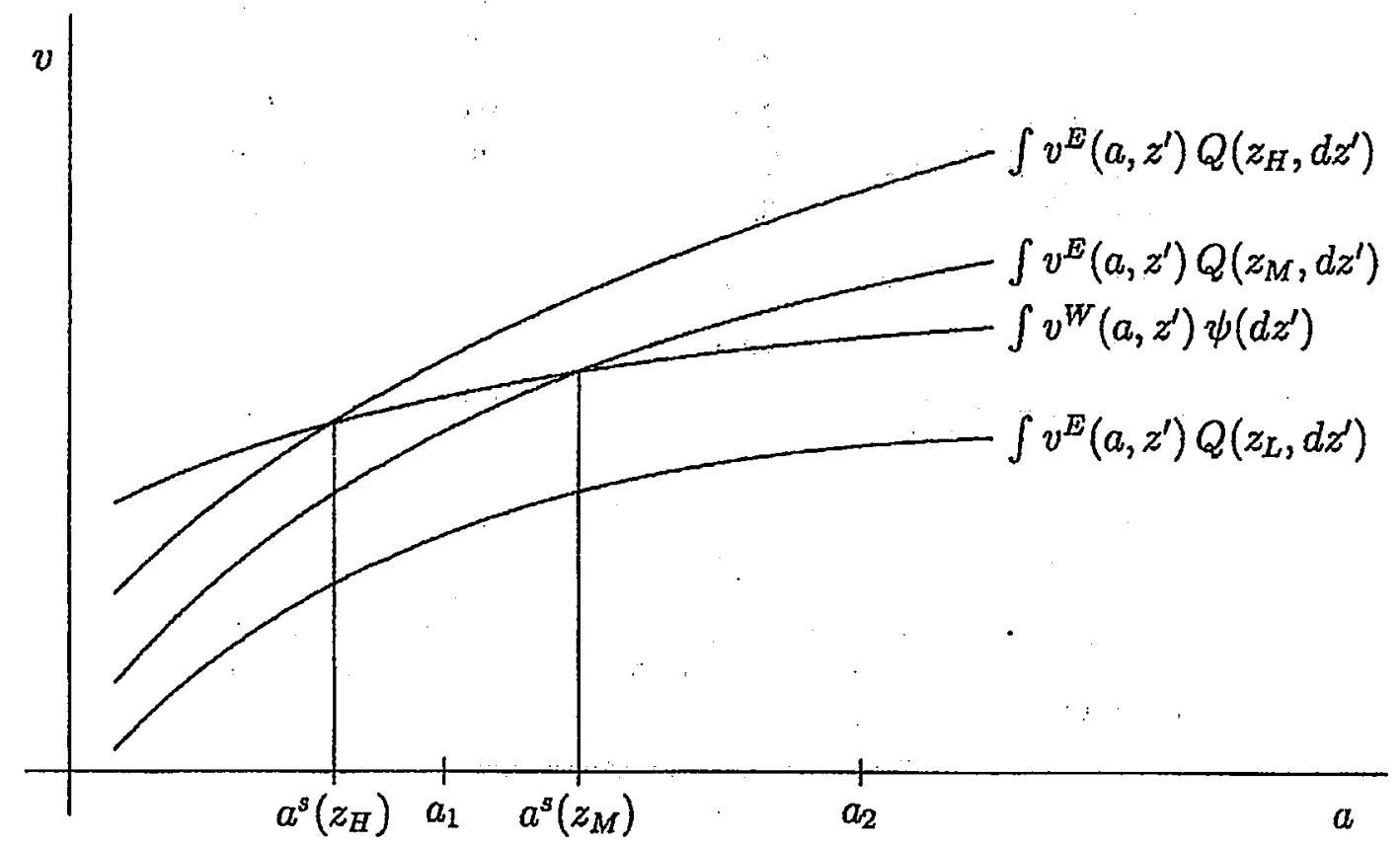

Figure 1: Value functions of entrepreneurs and workers 


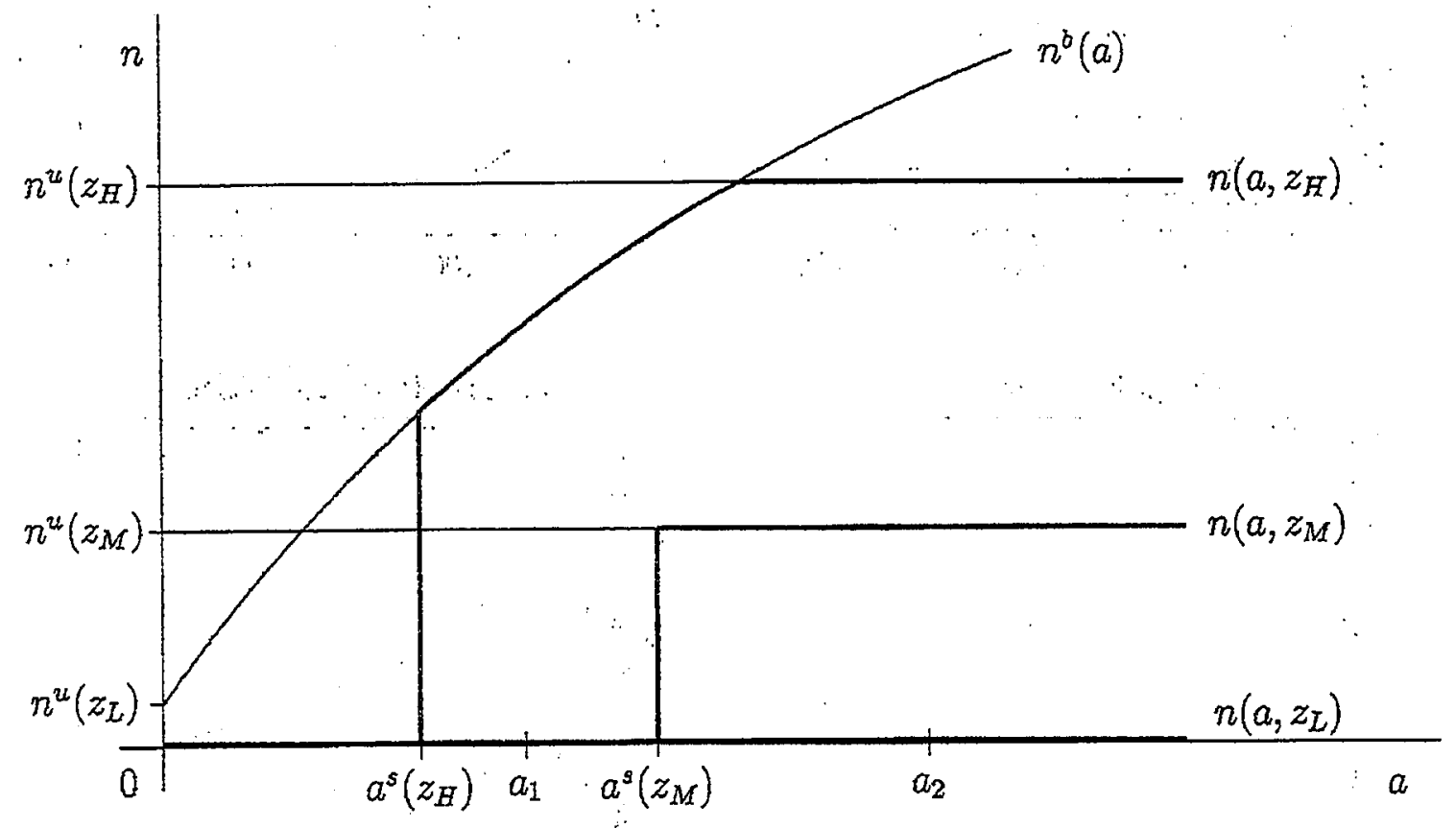

Figure 2: Hiring policies of entrepreneurs 

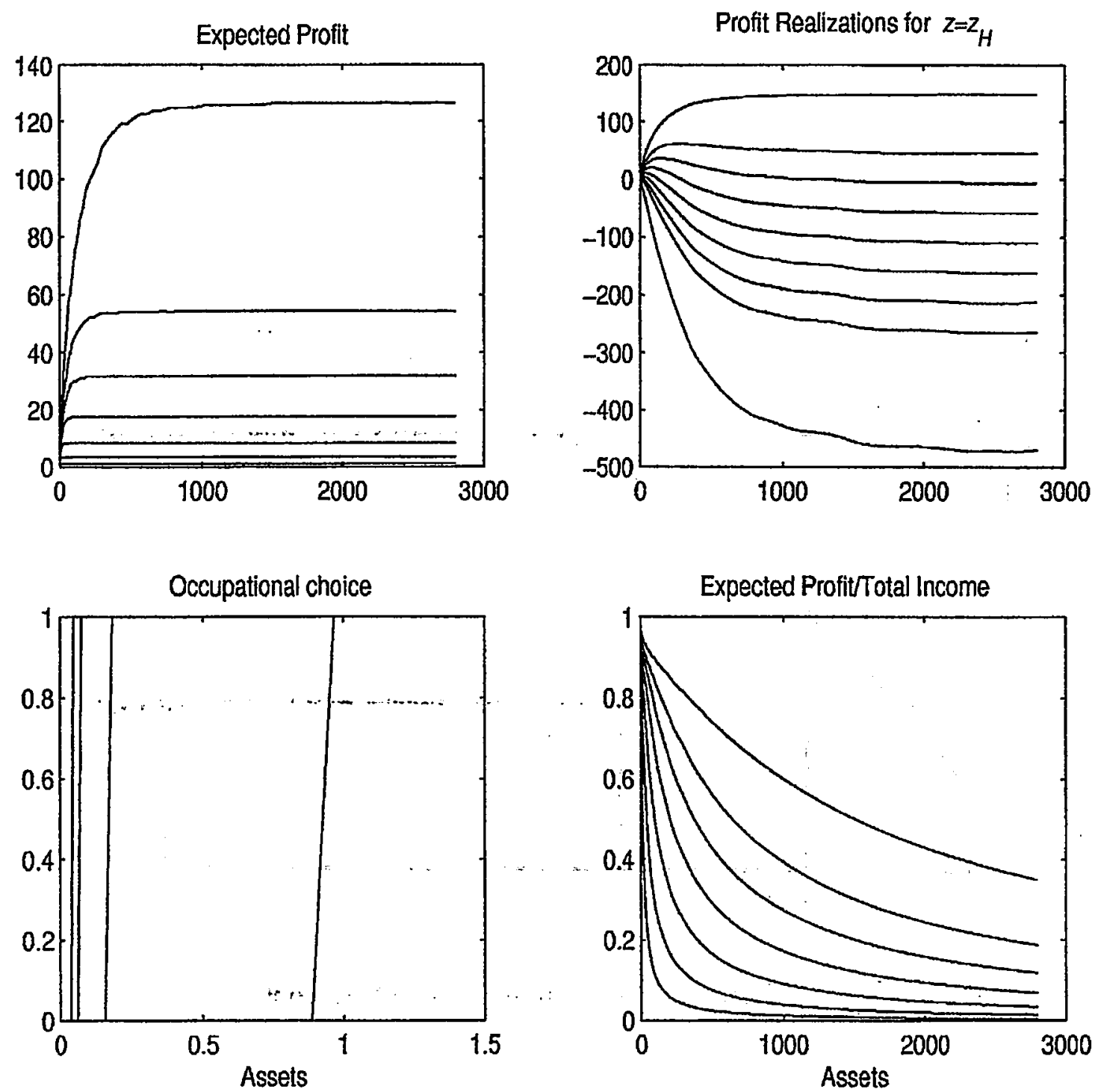

Expected profit and expected profit to total income for each signal ability shock $z$, both increasing in $z$. Occupational choice for each ability shock $z$, agents with higher $z$ switch to entrepreneurship (labelled as 1) at lower asset levels. Profit realizations conditional on the high signal ability shock; increasing in effective ability shock $z^{\prime}$.

Figure 3: Benchmark Economy: Profit and Occupational Choice. 

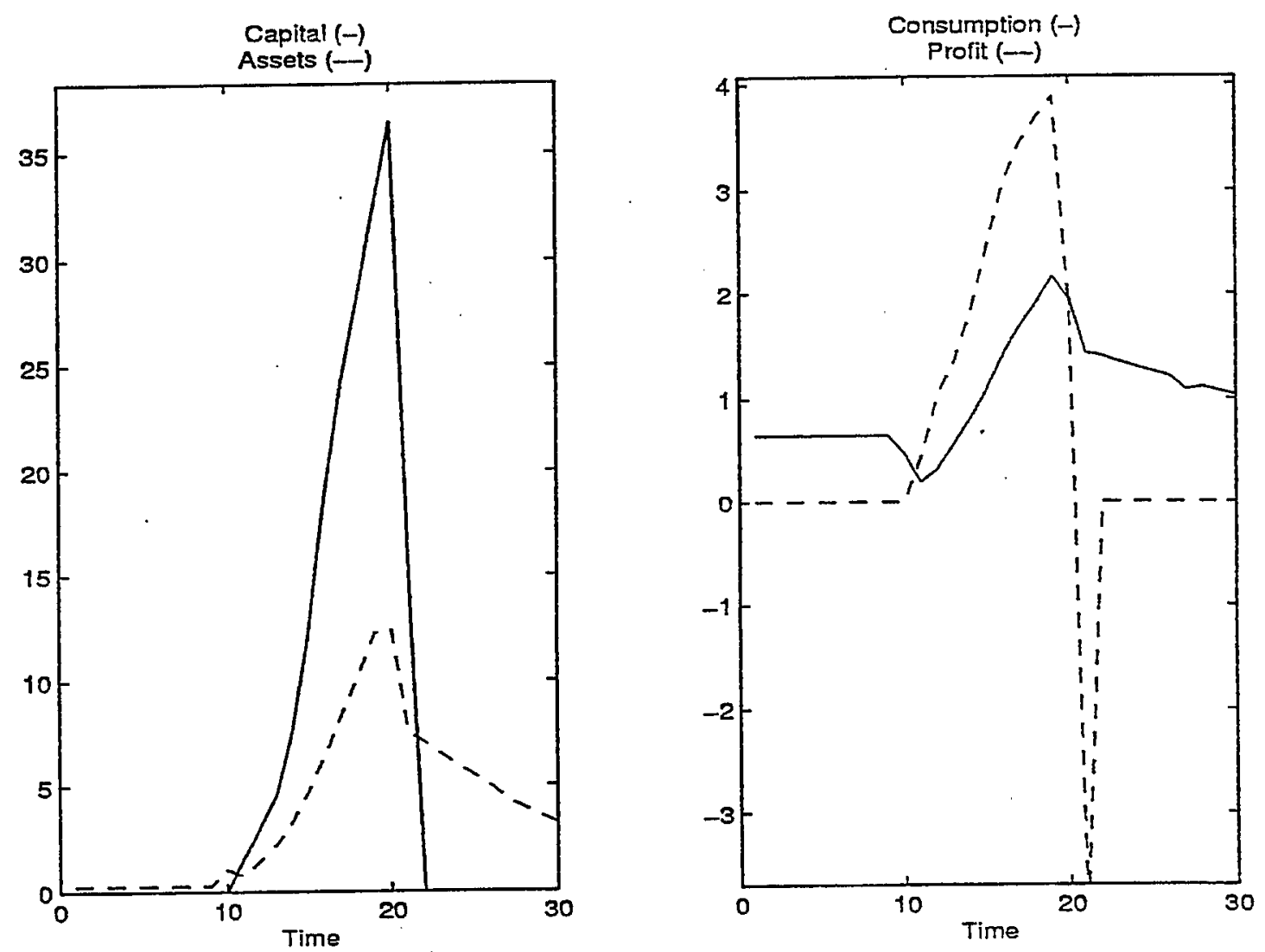

Time path for capital used in production, accumulated assets, consumption and profit for an agent who becomes an entrepreneur in periods 11-21 in the benchmark economy with financial intermediation.

Figure 4: Entrepreneurial Decisions: Time Path. 


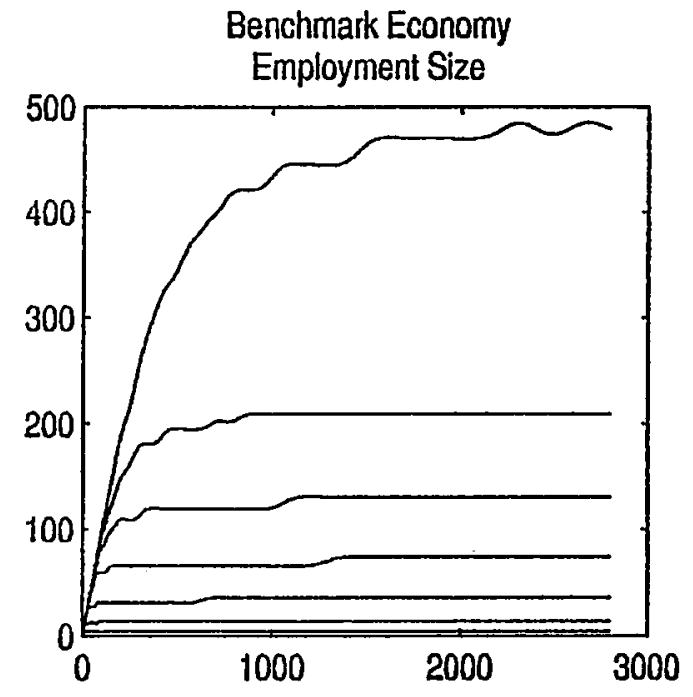

Economy Without Financial Intermediation Employment Size
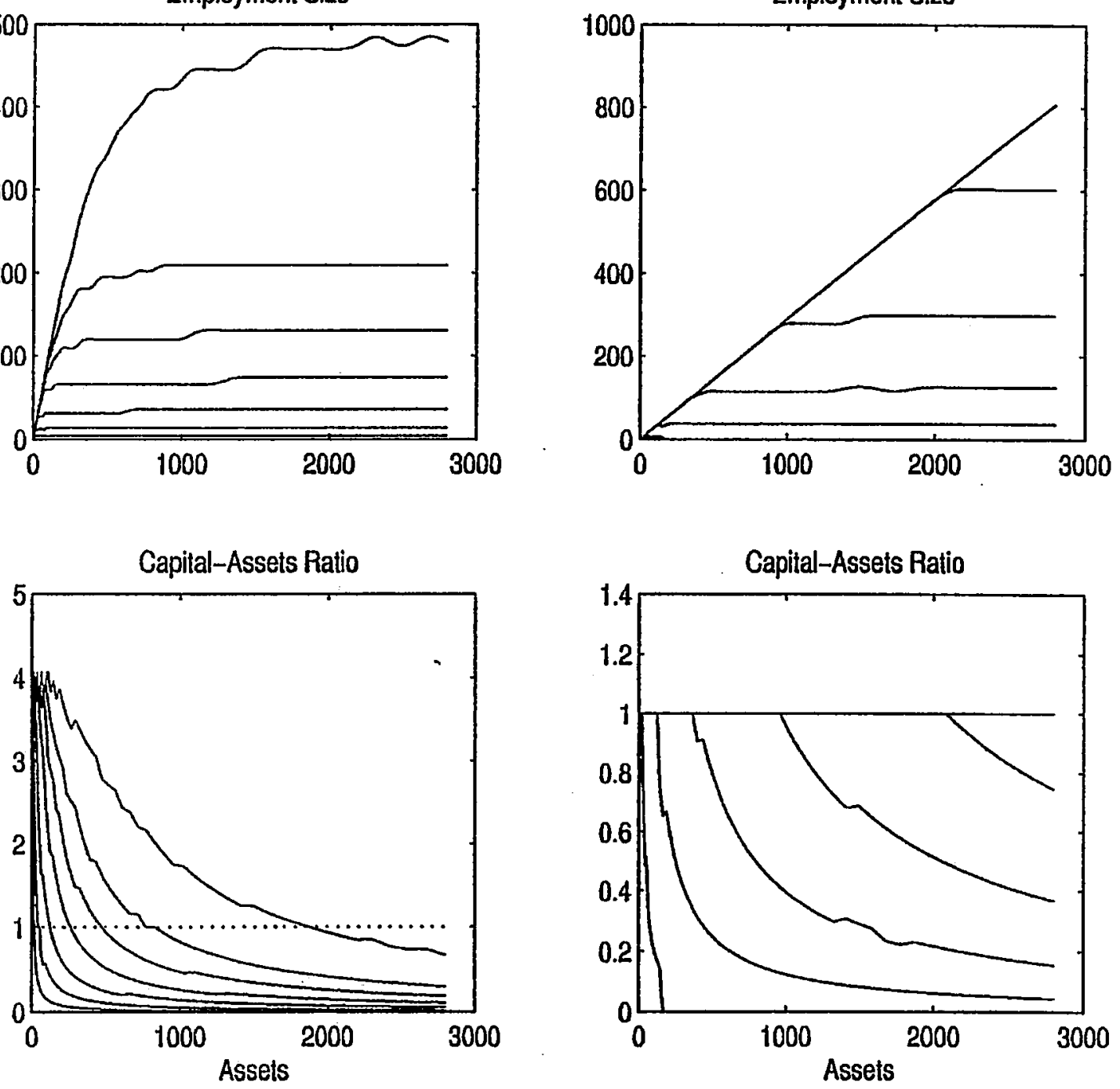

Employment policy and capital-asset ratio for the benchmark economy and in the economy without financial intermediation. All allocations conditional on and increasing in the signal ability shock $z$.

Figure 5: Entrepreneurial Decisions. 

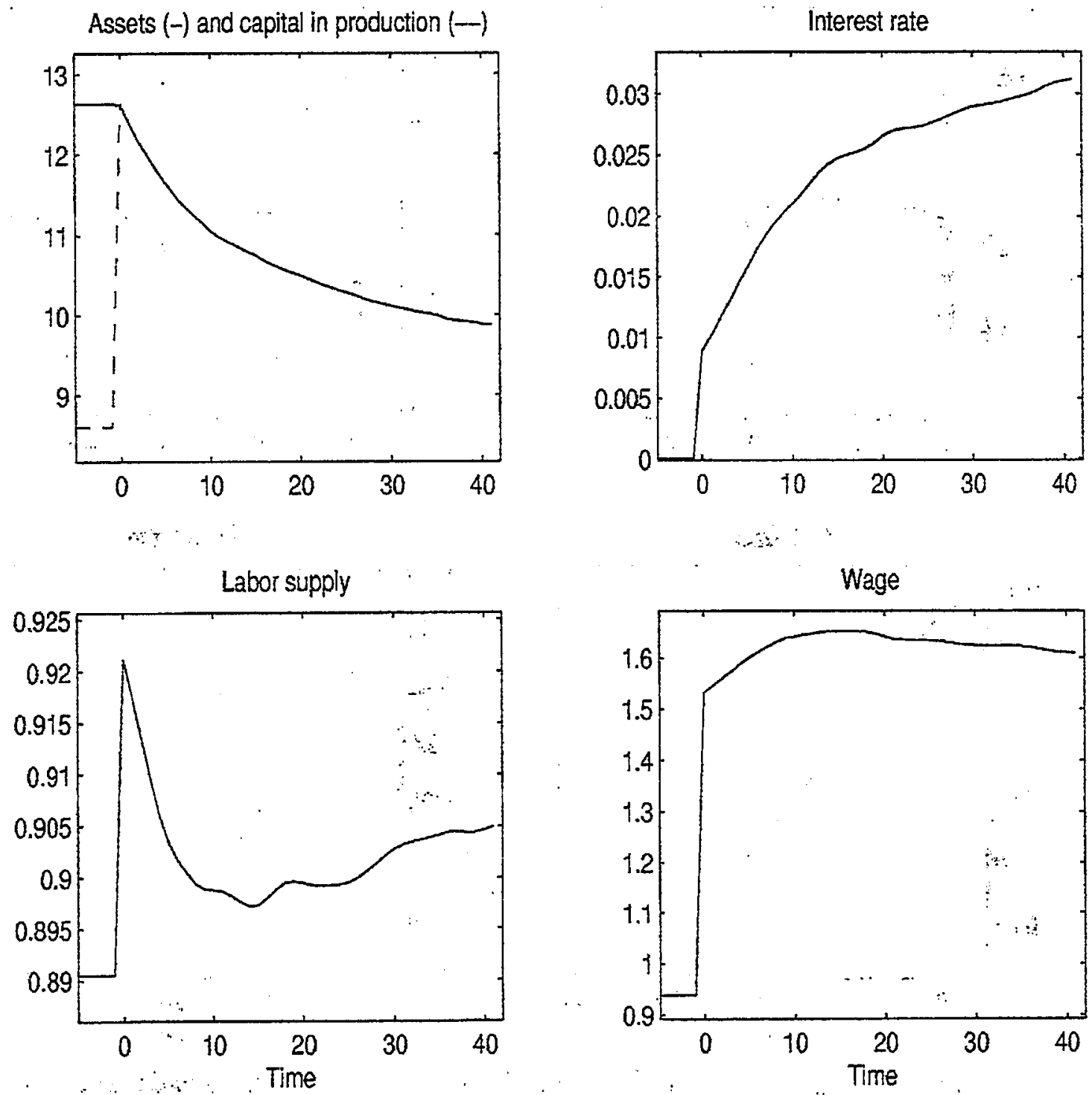

Figure 6: Transition: Capital and Labor Markets. 

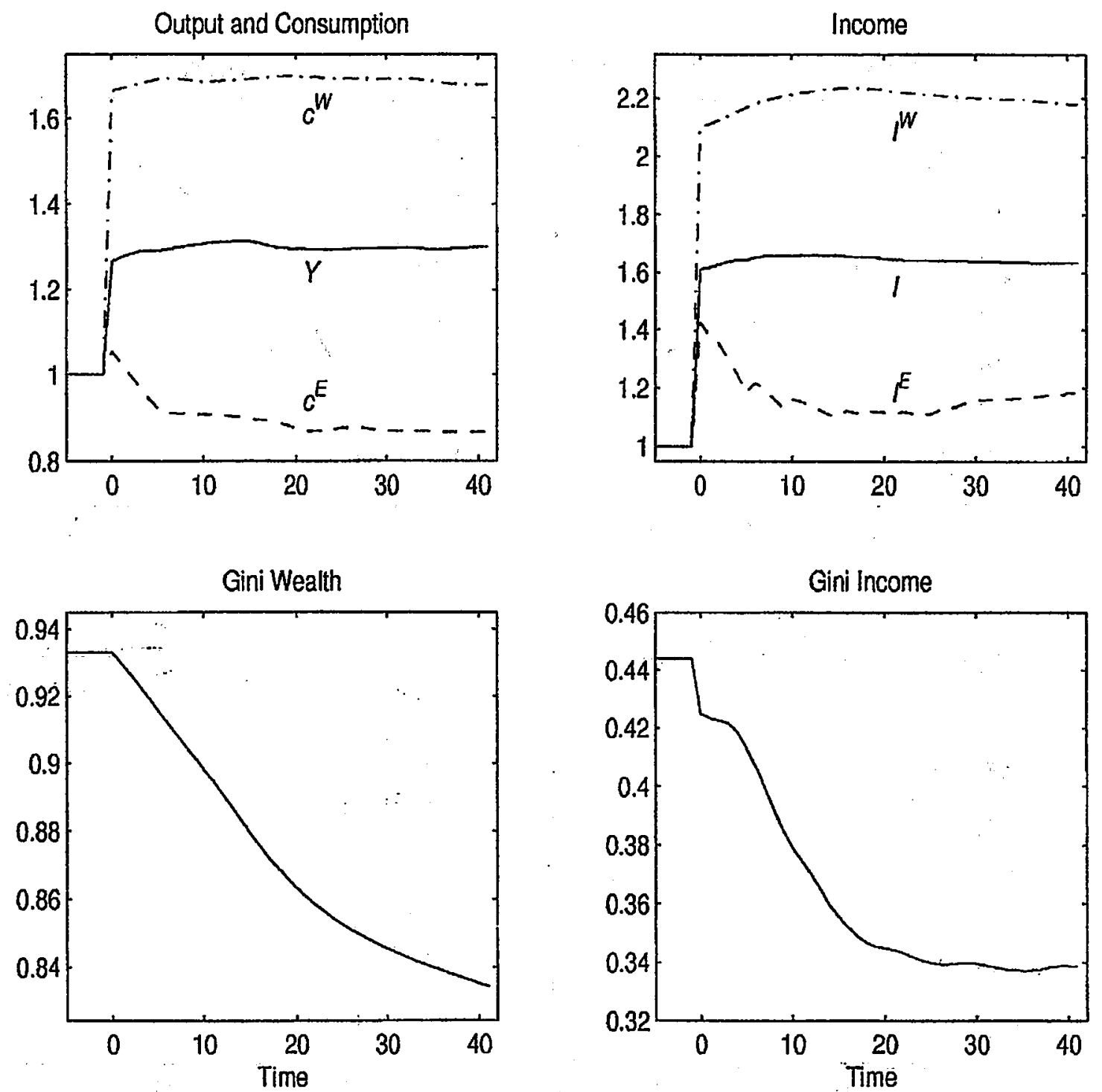

Output; consumption and income levels relative to the steady state of the economy without financial intermediation: average (solid line, $Y, I$ ), average for entrepreneurs (dashed line, $c^{E}, I^{E}$ ), average for workers (dashdotted line, $\left.c^{W}, I^{W}\right)$.

Figure 7: Transition: Allocations and Inequality. 
CERGE-EI

P.O.BOX 882

Politických vězňů 7

11121 Praha 1

Czech Republic http://www.cerge-ei.cz 